\title{
HUBUNGAN ASUPAN ENERGI, PROTEIN, SENG, DAN KEBUGARAN FISIK DENGAN PRESTASI BELAJAR ANAK STUNTING DI SDN PENGANTEN I, II, DAN III KECAMATAN KLAMBU KABUPATEN GROBOGAN
}

\author{
Ahmad Shokibi, Nuryanto*) \\ Program Studi Ilmu Gizi Fakultas Kedokteran Universitas Diponegoro \\ J1.Dr.Sutomo No.18, Semarang, Telp (024) 8453708, Email : gizifk@ undip.ac.id
}

\begin{abstract}
Background:Stunted children have lower academic performance compared with non-stunted children. Other factors which can affect academic performance are energy, protein, zinc intake, and physical fitness. Stunted children may have good academic performance if either energy, protein, zinc intake or physical fitness is fulfilled.

Purpose : To analyse the relationship between energy, protein, zinc intake, and physical fitness with stunted children's academic performance

Methods: An analitical observation with cross-sectional design on 67 stunted students grade $3^{\text {rd }}-6^{\text {th }}$ in I, II, and III Penganten Elementary School was conducted. Energy, protein, and zinc intake were obtained from Semi Quantitative Food Frequency Questionnaire (FFQ), physical fitness was obtained from Harvard Step Test for Elementary School Age, academic performance was measured by the average of mathematics, Indonesian, and Natural science scores in latest semester (January-June 2014). Correlation of energy, protein, zinc intake, and physical fitness with academic performance were tested using Pearson test.

Results:The average of energy, protein, and zinc intake are $1648 \pm 809 \mathrm{kkal}, 68 \pm 25 \mathrm{gr}, 7.1 \pm 2.6 \mathrm{mg}$ respectively with most subjects intake level of energy, protein, and zinc intake are low (46.3\%), high (66.7 \%), and low (80.6\%) respectively. The average of physical fitness score is $59 \pm 15$ with most subjects are in middle category (61.2\%). The average of academic performance score is $75 \pm 7$. There is positive correlation between physical fitness with stunted children's academic performance ( $p<0.05, r: 0.744)$. There is no correlation between energy, protein, dan zinc intake with stunted children's academic performance $(p>0.05)$.

Conclusions: Physical fitness proven has relationship with stunted children's academic performance. Energy, protein, and zinc intake not proven has relationship with stunted children's academic performance.

Keywords: energy; protein and zinc intake; physical fitness; academic performance; Stunted children
\end{abstract}

\begin{abstract}
ABSTRAK
Latar Belakang : Prestasi belajar anak stunting lebih rendah dibanding anak non-stunting.Faktor lain yang mempengaruhi prestasi belajar adalah asupan energi, protein, seng, dan kebugaran fisik, sehingga apabila asupan dan kebugaran anak stunting baik maka ada harapan prestasi belajarnya juga baik.

Tujuan : Mengetahui hubungan asupan energi, protein, seng, dan kebugaran fisik dengan prestasi belajar anak stunting

Metode : Jenis penelitian ini adalahanalitic observational dengan desaincross-sectionalpada 67 murid stuntingkelas III - VI SDN Penganten I, II, dan III. Data asupan energi, protein, dan seng diperoleh melalui Semi Quantitative Food Frequency Questionnaire (FFQ), data kebugaran fisik diperoleh melalui harvard step test untuk anak usia Sekolah Dasar, data prestasi belajar diperoleh dari rata-rata nilai matematika, bahasa Indonesia, dan IPA semester terakhir (Januari-Juni 2014) yang diperoleh dari rapor. Hubungan asupan energi, protein, seng, dan kebugaran fisik dengan prestasi belajar menggunakan uji Pearson.

Hasil : Rerata asupan energi, protein, dan seng subjek berturut-turut $1648 \pm 809 \mathrm{kkal}, 68 \pm 25 \mathrm{gr}, 7.1 \pm 2.6 \mathrm{mg}$ dengan sebagian besar tingkat kecukupan energi, protein, dan seng subjek berturut-turut adalah rendah (46.3\%), tinggi (66.7\%), rendah (80.6\%). Rerata skor kebugaran fisik subjek $59 \pm 15$ dengan sebagian besar masuk kategori tingkat kebugaran sedang $(61.2 \%)$. Rerata nilai prestasi belajar subjek sebesar $75 \pm 7$. Terdapat hubungan positif antara kebugaran fisik dengan prestasi belajar anak stunting ( $r: 0.744, p<0.05)$. Tidak ada hubungan antara asupan energi, protein, dan seng dengan prestasi belajar anak stunting ( $p>0.05)$.

Kesimpulan : Kebugaran fisik terbukti berhubungan dengan prestasi belajar anak stunting, dimana semakin baik kebugaran fisik anak stunting maka prestasi belajarnya juga semakin baik.Asupan energi, protein, dan seng tidak terbukti memiliki hubungan dengan prestasi belajar anak stunting.
\end{abstract}

Kata Kunci : Asupan Energi; Asupan Protein; Asupan Seng; Kebugaran Fisik; Prestasi Belajar; Stunting

\section{PENDAHULUAN}

Stunting pada anak Sekolah Dasar (7-12

tahun) merupakan manifestasi dari stunting pada masa balita. Dampak stunting pada anak salah satunya adalah prestasi belajar yang lebih rendah dibanding anak non-stunting. ${ }^{1}$ Selama proses

${ }^{*}$ Penulis Penanggungjawab 
menjadi stunting dapat terjadi kerusakan struktural dan fungsional otak. ${ }^{2}$ Gangguan pertumbuhan otak dalam jangka panjang pada anak stunting akan menyebabkan perubahan metabolisme neurotransmitter hingga perubahan anatomi otak. Perubahan tersebut kemudian membatasi kapasitas intelektual anak stunting secara permanen, yang kemudian berdampak pada prestasi belajar yang rendah. ${ }^{2,3}$ Prestasi belajar juga dipengaruhi oleh faktor lain diantaranya asupan energi, protein, seng, dan kebugaran fisik, sehingga apabila asupan dan kebugaran anak stunting baik maka ada harapan prestasi belajarnya juga baik. ${ }^{4-6}$

Penelitian pada murid SD non-stunting di Korea menunjukkan bahwa asupan energi yang cukup berhubungan dengan prestasi belajar yang lebih baik. ${ }^{5}$ Pengaruh energi terhadap prestasi belajar berhubungan dengan kemampuannya dalam menaikkan kadar gula darah sebagai sumber energi otak. Selain sebagai sumber energi, peningkatan kadar gula darah akan meningkatkan produksi asetilkolin yang berfungsi sebagai penghantar sinyal saraf-saraf otak. ${ }^{7,8}$

Asupan protein juga mempengaruhi prestasi belajar anak. Penelitian di Lampung pada anak murid non-stunting menunjukkan bahwa asupan protein berhubungan dengan prestasi belajar murid. ${ }^{9}$ Efek tersebut diperantarai oleh peningkatan kadar asam amino dan kolin yang merupakan prekursor neurotransmitter. Sekresi neurotransmitter tersebut dapat memperbaiki kondisi psikologis atau mood sehingga memperbaiki proses penalaran. ${ }^{10}$

Asupan seng juga mempengaruhi prestasi belajar. Penelitian tentang hubungan asupan seng dengan prestasi belajar murid SD non-stunting di Korea menunjukkan bahwa semakin tinggi asupan seng maka prestasi belajar juga semakin baik. ${ }^{5}$ Dampak terhadap prestasi belajar oleh seng merupakan akibat dari kemampuan seng dalam mempengaruhi perkembangan neurotransmitter, dimana perkembangan neurotranmitter akan terganggu apabila terjadi defisiensi seng. Gangguan neurotransmitter menyebabkan gangguan penyampaian sinyal ke otak melalui berbagai mekanisme, sehingga menurunkan kemampuan kognitif anak. ${ }^{11}$

Kebugaran fisik juga mempengaruhi prestasi belajar siswa. Penelitian tentang hubungan kebugaran fisik dengan prestasi belajar siswa SD non-stunting di Amerika menunjukkan bahwa terdapat hubungan antara kebugaran otot anak SD dengan nilai tes matematika dan bahasa. ${ }^{12} \mathrm{Hal}$ tersebut disebabkan oleh peningkatan aliran darah ke otak sehingga kebutuhan oksigen otak terpenuhi dengan lebih baik. Selain itu, juga disebabkan oleh adanya perubahan kadar neurotransmitter yang memberikan efek tenang pada anak. ${ }^{13,14}$

Prevalensi anak stunting usia 7-12 tahun di Indonesia sangat tinggi. Berdasarkan data Riset Kesehatan Dasar (RISKESDAS) tahun 2013 menunjukkan bahwa prevalensi anak stunting pada usia 7-12 tahun adalah $37,2 \%$ dengan $18 \%$ sangat pendek dan $29,2 \%$ pendek. ${ }^{15}$ Salah satu Kabupaten di Jawa Tengah dengan prevalensi stunting tinggi adalah Kabupaten Grobogan. ${ }^{16}$ Berdasarkan hasil penelitian awal terhadap SD di Desa Penganten Kecamatan Klambu Kabupaten Grobogan diketahui bahwa prevalensi stunting di Desa Penganten sebesar 25\%.

\section{METODE}

Penelitian ini dilakukan di Desa Penganten Kecamatan Klambu Kabupaten Grobogan pada bulan November 2014. Sampel merupakan siswa kelas III - VI Sekolah Dasar Negeri Penganten 1, 2 , dan 3. Jenis penelitian ini yaitu analitic observational dengan desain cross-sectional. Variabel bebas dalam penelitian ini adalah asupan energi, protein, seng, dan tingkat kebugaran. Variabel terikat dalam penelitian ini adalah prestasi belajar.

Penelitian diawali dengan skrining data berdasarkan kriteria inklusi. Salah satu kriteria inklusi penelitian ini adalah stunting, yang diidentifikasi berdasarkan umur melalui pengukuran antropometri tinggi badan menggunakan microtoise dengan ketelitian $0.1 \mathrm{~cm}$ dan WHO anthroplus 2007, kemudian dilanjutkan dengan penentuan sampel penelitian sebesar 77 subjek yang ditentukan secara simple random sampling. Dari jumlah tersebut tersisa 67 subjek yang bersedia menjadi subyek penelitian.

Subjek yang bersedia kemudian diambil datanya. Data yang dikumpulkan adalah data karakteristik subjek, data asupan energi, protein, seng, data tingkat kebugaran, dan data prestasi belajar. Data asupan energi, protein, dan seng diperoleh melalui metode Semi Quantitative Food Frequency Questionnaire (FFQ) yang kemudian diolah menggunakan Nutrisurvey for Windows 2005. Proses wawancara tersebut dilaksanakan dengan pendampingan dari orang tua subjek.

Data tingkat kebugaran diperoleh dengan menggunakan metode Harvard Step Test untuk anak usia Sekolah Dasar. Data prestasi belajar anak diperoleh dari rata-rata nilai raport semester terakhir (Januari-Juli 2014) pada mata pelajaran Bahasa Indonesia, Matematika, dan IPA. Rerata 
nilai diperoleh dengan cara menjumlahkan ketiga mata pelajaran tersebut dan kemudian dibagi tiga.

Data diuji normalitasnya dengan uji Kolmogorov Smirnov. Korelasi asupan energi, protein, seng, dan tingkat kebugaran (skor PEI) dengan prestasi belajar diuji menggunakan uji korelasi Pearson.

\section{HASIL PENELITIAN}

Karakteristik Subjek

Subjek penelitian ini adalah 67 anak stunting dengan rerata usia $9 \pm 1$ tahun. Data jenis kelamin, pendidikan ibu dan ayah, dan kemampuan ekonomi tersaji dalam tabel 1.

Tabel 1. Jenis Kelamin, Pendidikan Ibu, Pendidikan Ayah, dan Kemampuan Ekonomi Subjek

\begin{tabular}{ccc}
\hline Karakteristik & $\mathbf{n}$ & $\mathbf{\%}$ \\
\hline Jenis kelamin & 32 & 47.8 \\
Laki - Laki & 35 & 52.2 \\
Perempuan & & 46.3 \\
Pendidikan ibu & 31 & 38.8 \\
Tamat SD & 26 & 10.4 \\
Tamat SMP & 7 & 4.5 \\
Tamat SMA & 3 & 52.2 \\
Perguruan tinggi & & 28.4 \\
Pendidikan ayah & 35 & 13.4 \\
Tamat SD & 19 & 6 \\
Tamat SMP & 9 & \\
Tamat SMA & 4 & 53.7 \\
Perguruan tinggi & & 46.3 \\
Kemampuan ekonomi & 36 & \\
Kurang mampu & 31 & \\
Mampu & & \\
\hline
\end{tabular}

Tabel 1 menunjukkan bahwa pendidikan ibu dan ayah subjek paling banyak adalah lulusan $\mathrm{SD}$, dan berasal dari keluarga dengan kemampuan ekonomi kurang mampu (53.7\%).

Prestasi Belajar
Prestasi belajar diperoleh dengan cara menjumlahkan tiga mata pelajaran (Matematika, Bahasa Indonesia, IPA) kemudian dibagi tiga. Hasil penelitian diperoleh prestasi belajar subjek seperti yang tersaji dalam tabel 2 .

Tabel 2. Rerata Nilai Mata Pelajaran Matematika, Bahasa Indonesia, dan IPA Subjek

\begin{tabular}{lccccc}
\hline \multicolumn{1}{c}{ Mata pelajaran } & $\mathbf{n}$ & Rerata & $\begin{array}{c}\text { Simpang } \\
\text { baku }\end{array}$ & Rerata nilai kelas & $\begin{array}{c}\text { Selisih } \\
(\Delta)\end{array}$ \\
\hline Matematika (skor) & 67 & 72 & 7 & 72 & 0 \\
Bahasa indonesia (skor) & 67 & 77 & 8 & 75 & 2 \\
IPA (skor) & 67 & 75 & 8 & 72 & 3 \\
\hline Prestasi belajar (skor) & 67 & 75 & 7 & 74 & 1 \\
\hline
\end{tabular}

Tabel 2 menunjukkan bahwa rerata nilai subjek pada ketiga mata pelajaran dan rerata prestasi belajar sedikit lebih tinggi dari rerata nilai kelasnya. Distribusi nilai subjek menurut rata-rata nilai kelas tersaji dalam tabel 3 .

Tabel 3. Distribusi Nilai Subjek Menurut Rata-rata Nilai Kelas

\begin{tabular}{lccccccc}
\hline \multicolumn{1}{c}{ Mata pelajaran } & $\mathbf{n}$ & \multicolumn{2}{c}{$\begin{array}{c}\text { Dibawah rerata nilai } \\
\text { kelas }\end{array}$} & $\begin{array}{c}\text { Sama dengan rerata } \\
\text { nilai kelas }\end{array}$ & \multicolumn{2}{c}{$\begin{array}{c}\text { Diatas rerata nilai } \\
\text { kelas }\end{array}$} \\
\cline { 3 - 9 } & & $\mathbf{n}$ & $\mathbf{\%}$ & $\mathbf{n}$ & $\mathbf{\%}$ & $\mathbf{n}$ & \% \\
\hline Matematika (skor) & 67 & 35 & 52.2 & 6 & 9 & 26 & 38.8 \\
Bahasa Indonesia (skor) & 67 & 33 & 49.3 & 1 & 1.4 & 33 & 49.3 \\
IPA (skor) & 67 & 38 & 56.7 & 2 & 3 & 27 & 40.3 \\
\hline Total & & 106 & 52.7 & 9 & 4.5 & 86 & 42.8 \\
\hline
\end{tabular}

Tabel 3 menunjukkan bahwa subjek paling banyak memiliki tingkat nilai dibawah rerata nilai kelas.

\section{Asupan Energi, Protein, dan Seng}

Zat gizi yang dilihat dalam penelitian ini adalah asupan energi, protein, dan seng seperti yang tersaji dalam tabel 4. 
Tabel 4. Asupan Energi, Protein, dan Seng Subjek

\begin{tabular}{lcccc}
\hline \multicolumn{1}{c}{ Asupan } & n & Rerata & Simpang baku & Kebutuhan \\
\hline Energi (kkal) & 67 & 1643 & 809 & $1850-2100$ \\
Protein (gr) & 67 & 68 & 25 & $49-60$ \\
Seng (mg) & 67 & 7.1 & 2.6 & $11-14$ \\
\hline
\end{tabular}

Tabel 4 menunjukkan bahwa rerata asupan energi dan seng subjek memenuhi kebutuhan, sedangkan rerata asupan protein subjek melebihi kebutuhan. Tingkat asupan subjek dikategorikan berdasarkan Angka Kecukupan Gizi (AKG) 2013. Distribusi tingkat asupan energi, protein, dan seng tergambar pada tabel 5.

Tabel 5. Distribusi Tingkat Asupan Energi, Protein, dan Seng Subjek

\begin{tabular}{lcccccc}
\hline \multirow{2}{*}{ Asupan } & \multicolumn{2}{c}{ Rendah } & \multicolumn{2}{c}{ Cukup } & \multicolumn{2}{c}{ Tinggi } \\
\cline { 2 - 7 } & n & \% & n & \% & n & \% \\
\hline Energi (kkal) & 31 & 46.3 & 26 & 37.3 & 11 & 16.4 \\
Protein (gr) & 12 & 17.9 & 11 & 16.4 & 44 & 66.7 \\
Seng (mg) & 54 & 80.6 & 11 & 16.4 & 2 & 3 \\
\hline
\end{tabular}

Tabel 4 menunjukkan bahwa sebagian besar subjek memiliki asupan energi yang rendah $(46.3 \%)$, dan lebih dari setengah total subjek memiliki asupan protein tinggi $(66.7 \%)$, serta asupan seng yang rendah $(80.6 \%)$.

\section{Kebugaran Fisik}

Kebugaran fisik subjek memiliki rerata skor kebugaran sebesar $59 \pm 15$. Skor kebugaran

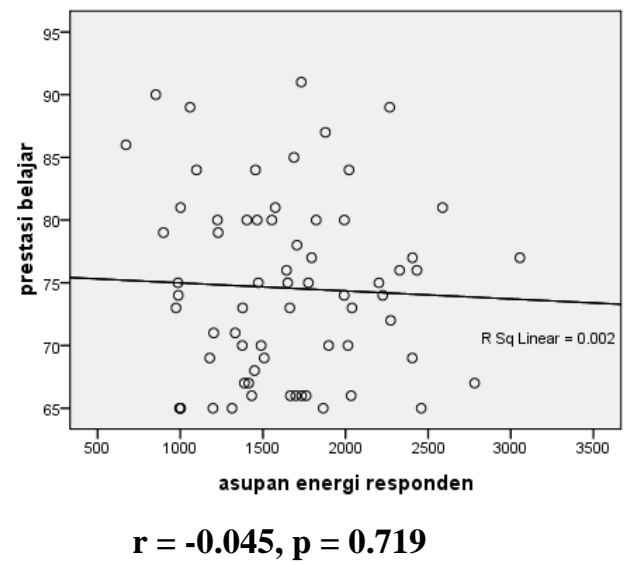

Gambar 1. Hubungan asupan energi dengan prestasi belajar anak stunting subjek apabila dikategorikan maka 20 anak (29.9\%) memiliki tingkat kebugaran kurang, 41 anak $(61.2 \%)$ sedang, dan 6 anak (9\%) sangat baik.

Hubungan Antar Variabel

Analisa hubungan asupan energi, protein, seng, dan kebugaran fisik dengan prestasi belajar anak stunting tersaji dalam gambar 1, 2, 3, dan 4 .

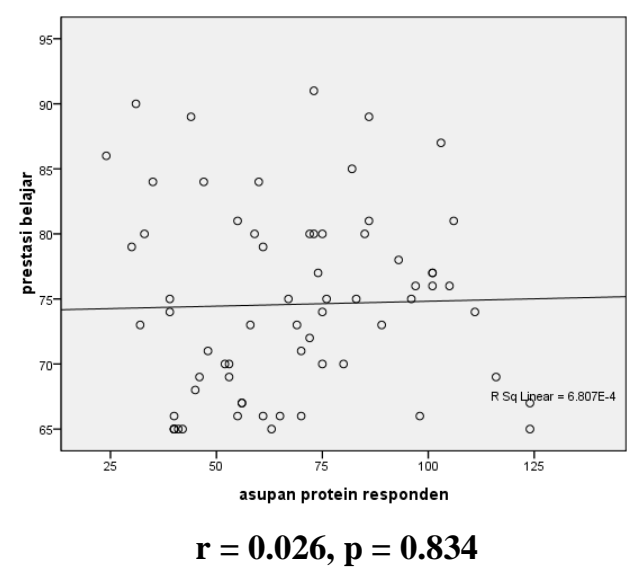

Gambar 2. Hubungan asupan protein dengan prestasi belajar anak stunting

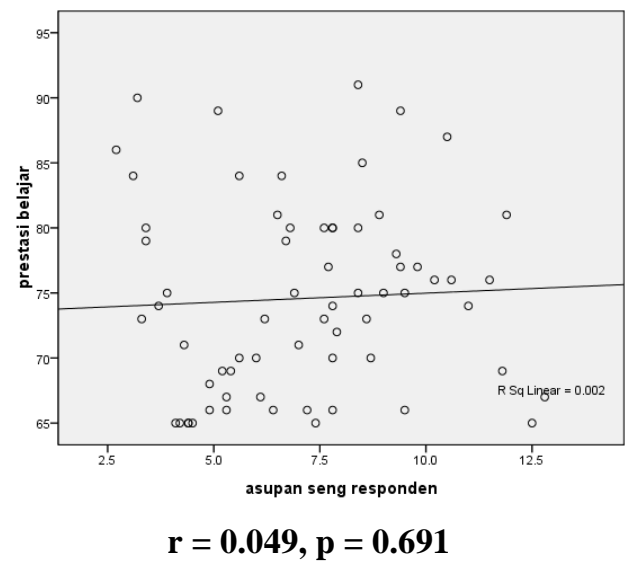

Gambar 3. Hubungan asupan seng dengan prestasi belajar anak stunting 
Gambar 1, 2, dan 3 menunjukkan bahwa dan seng dengan prestasi belajar anak stunting tidak ada hubungan antara asupan energi, protein, $\quad(p>0.05)$.

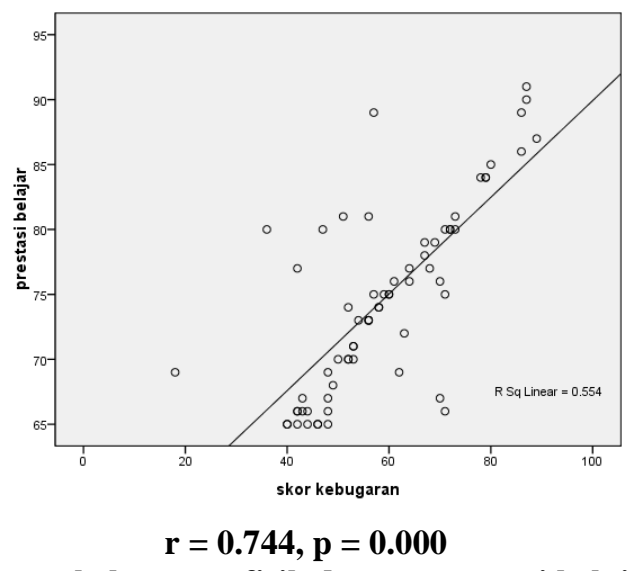

Gambar 4. Hubungan kebugaran fisik dengan prestasi belajar anak stunting

Gambar 4 menunjukkan bahwa ada hubungan positif antara kebugaran fisik dengan skor prestasi belajar anak stunting. Artinya semakin tinggi kebugaran anak stunting maka prestasi belajarnya juga akan semakin tinggi.

\section{PEMBAHASAN}

Penelitian ini diketahui bahwa prestasi belajar sebagian besar subjek dibawah rerata nilai kelas. Keterkaitan antara tinggi tubuh dengan kinerja kognitif sangat besar pada berbagai kelompok etnis serta wilayah geografik. Keterkaitan ini kemudian ditafsirkan sebagai dampak dari status gizi selama periode perkembangan otak terhadap perkembangan kognitif, dimana anak stunting terus menunjukkan kemampuan prestasi belajar yang lebih rendah dibandingkan dengan anak non-stunting dari masa anak-anak dini (5 - 7 tahun) hingga usia 12 tahun. ${ }^{17}$ Stunting masa anak-anak adalah manifestasi stunting masa balita, yang merupakan periode emas pertumbuhan otak. Selama proses menjadi stunting, terjadi kerusakan struktural dan fungsional otak baik bersifat permanen maupun recoveri, tetapi proses recoveri tidak mampu mengembalikan seperti kondisi normal. Kerusakan tersebut mengakibatkan gangguan otak secara permanen sehingga membatasi kapasitas intelektual dan perlambatan perkembangan kognitif anak stunting secara permanen. ${ }^{18}$ Anak stunting juga memiliki permasalahan perilaku, lebih terhambat, dan kurang perhatian, serta lebih menunjukkan gangguan perilaku (conduct disorder) yang diakibatkan oleh terganggunya perkembangan motorik dan mental karena dampak stunting. Mereka tidak begitu mengeksplorasi lingkungannya dan menggunakan tipe-tipe manipulasi yang lebih sedikit jika dibandingkan dengan anak-anak non-stunting. Mereka juga memperlihatkan penurunan respons orientasi terhadap rangsangan pada pendengaran dan penglihatan, padahal hal tersebut berperan besar dalam akifitas belajar karena menentukan tingkat informasi yang akan diterima dan diolah oleh anak tersebut. ${ }^{17}$

Kondisi gizi kurang (stunting) berkaitan sangat erat dengan kadar seng yang lebih rendah dalam tubuh. Defisiensi seng dapat menyebabkan gangguan imunitas sehingga meningkatkan risiko terkenan infeksi. Dibandingkan dengan orang berstatus gizi cukup, orang dengan status gizi kurang lebih cenderung mengalami penyakit diare, malaria, dan infeksi saluran pernafasan. Selain itu, juga memiliki kemungkinan lebih besar untuk menderita semua penyakit tersebut dengan durasi lebih lama dan mengalami gejala sisa (sequele) yang akan melemahkan keadaan mereka. Kondisi tersebut mempengaruhi penggunaan zat gizi pada hospes. Interaksi antara status gizi dan infeksi dalam tubuh hospes dikemukakan sebagai peristiwa sinergistik. Beberapa respon hospes terhadap infeksi yang mempengaruhi status gizi antara lain penurunan selera makan (anoreksia), malabsorbsi dalam saluran cerna, kehilangan nutrien, dan perubahan metabolisme. Keadaan tersebut mengakibatkan penurunan asupan energi sekitar 20\% dibawah asupan yang lazim, meningkatkan laju sintesis dan pemecahan protein sehingga terjadi penambahan kehilangan nitrogen dan keseimbangan nitrogen yang negatif, menurunkan absorbsi lemak dari makanan menjadi hanya $58 \%$ dari keadaan normalnya, menurunkan absorbsi protein dari makanan menjadi hanya $44 \%$ dari keadaan normalnya. Penurunan absorbsi 
makronutrien tersebut menyebabkan absorbsi energi dari makanan menjadi hanya sekitar $71 \%$ dari keadaan normalnya. ${ }^{17}$

Prestasi belajar yang rendah pada sebagian besar subjek juga diikuti oleh asupan seng yang rendah pada sebagian besar subjek meskipun pada penelitian ini didapatkan hasil tidak ada hubungan antara asupan seng dengan prestasi belajar subjek. Selain itu, penelitian ini juga didapatkan hasil tidak ada hubungan antara asupan energi dan protein dengan prestasi belajar subjek. Tidak adanya hubungan pada variabel asupan menunjukkan bahwa hasil penelitian tidak sesuai dengan teori. Secara teoritik diketahui bahwa asupan energi, protein, dan seng berperan terhadap prestasi belajar seseorang, baik melalui fungsi otak maupun psikososial. ${ }^{19}$ Hasil yang diperoleh pada variabel asupan tidak menutup kemungkinan merupakan akibat dari kelemahan pada pelaksanaan penelitian, diantaranya meliputi desain penelitian dan metode pengambilan data. Dibandingkan dengan desain lain, cross-sectional merupakan desain yang menyajikan hasil dengan kekuatan hubungan paling rendah. Selain itu, pengambilan data melalui food frequency questionaire memiliki kelemahan tersendiri. Meskipun metode tersebut sejauh ini merupakan metode terbaik dalam pengambilan data asupan, tetapi faktor bias data masih tergolong tinggi. Faktor tersebut merupakan keterbatasan dalam penelitian ini. ${ }^{20}$

Penelitian ini diketahui bahwa subjek memiliki asupan seng yang rendah tetapi memiliki asupan protein yang tinggi. Kandungan seng pada makanan biasanya mengikuti kandungan proteinnya, dimana semakin tinggi kandungan protein biasanya juga diikuti oleh kandungan seng yang juga tinggi. ${ }^{19}$ Hasil penelitian ini yang tidak sesuai dengan pernyataan tersebut mungkin disebabkan oleh adanya beberapa makanan yang diasup oleh subjek yang memiliki kandungan protein tinggi tetapi tidak diikuti oleh kandungan seng yang juga tinggi. Makanan tersebut diantaranya seperti ikan lele, bandeng, tahu, dan jajanan sekolah berupa sosis.

Penelitian ini didapatkan hasil bahwa kebugaran fisik berhubungan dengan prestasi belajar anak stunting. Hasil ini sesuai dengan penelitian pada anak SD non-stunting di Amerika yang menunjukkan adanya hubungan antara kebugaran fisik dengan prestasi belajar anak yang diukur dengan pencapaian nilai tes tahunan pada mata pelajaran matematika dan bahasa. ${ }^{12}$ Peran kebugaran fisik dengan prestasi belajar berkaitan dengan manfaat fisiologis dan psikologis. Salah satu fungsi fisiologis adalah peningkatan aliran darah serebral. Aliran darah yang meningkat akan menyediakan bahan bakar yang dibutuhkan otak dengan baik, yaitu oksigen. Pemenuhan oksigen yang baik berdampak terhadap tingkat konsentrasi yang juga baik. Penelitian tentang pengaruh administrasi oksigen 30\% menunjukkan bahwa seseorang dengan administrasi oksigen 30\% memiliki saturasi oksigen darah dan kemampuan kognitif yang lebih tinggi dibanding dengan oksigen $21 \%$ (konsentrasi oksigen udara bebas). ${ }^{21}$ Oksigen merupakan senyawa yang sangat penting karena dibutuhkan untuk metabolisme energi otak serta pertumbuhan dan penyembuhan (healing) saraf otak. Otak tidak mampu bertahan atau berfungsi normal dalam waktu lama tanpa oksigen. Kadar oksigen yang rendah baik secara kronis maupun akut dapat merusak syaraf yang kemudian berdampak negatif terhadap perkembangan, perilaku, dan prestasi akademik. ${ }^{21}$ Selain itu, mekanisme fisiologis juga berkaitan dengan perubahan aktivitas neurotransmisi otak seperti asetilkolin, dopamin, dan norepinephrin. Peningkatan sekresi neurotransmitter tersebut memberikan efek berupa rasa tenang dan mood lebih baik yang merupakan bagian dari fungsi psikologis. Psikologi positif dapat mempercepat perkembangan psikomotor, mengurangi rasa tegang, cemas, dan stres, dan meningkatkan percaya diri. Seseorang dengan psikologis positif memiliki kemampuan lisan dan perbendaharaan kata yang lebih baik, mampu mengkategorikan materi menjadi lebih sederhana, memiliki ketertarikan lebih besar terhadap suatu materi, dan memiliki opsi pemecahan masalah lebih baik sehingga memungkinkan seseorang mengorganisir ide dan melihat dari berbagai sudut pandang. Sebaliknya, kondisi psikologis negatif seperti stres akan mempersulit konsentrasi dan pengorganisasian pikiran secara logis. ${ }^{12,22}$

Penelitian ini didapatkan hasil bahwa kebugaran fisik memiliki hubungan dengan prestasi belajar subjek, sementara asupan energi, protein, dan seng tidak berhubungan. Hal tersebut secara tidak langsung menunjukkan bahwa tingkat kebugaran subjek tidak sesuai dengan tingkat asupan zat gizi subjek. Asupan zat gizi memang mempengaruhi tingkat kebugaran seseorang, tetapi bukan satu-satunya faktor. Kebugaran fisik merupakan multifaktorial, yang berarti pembentukannya dipengaruhi oleh berbagai faktor. Kebugaran seseorang selain dipengaruhi oleh asupan zat gizi, juga dipengaruhi oleh faktor predisposisi herediter dan aktivitas fisik. Gangguan pada salah satu faktor tersebut akan berdampak pada kebugaran, tetapi ada kemungkinan 
dampaknya tidak signifikan karena masih ada pengaruh dari faktor lain. Adanya hubungan yang berbeda antara variabel asupan zat gizi dengan kebugaran fisik pada penelitian ini mungkin berkaitan dengan hal tersebut. Kebugaran fisik yang baik dapat diperoleh melalui latihan atau melalui aktivitas fisik dalam rutinitas sehari-hari. Latihan atau aktivitas fisik baik aktivitas fisik terstruktur maupun aktivitas fisik tidak terstruktur seperti bersepeda, berjalan, berkebun, dan bermain memiliki efek yang kuat terhadap peningkatan kebugaran jantung dan paru-paru, serta kekuatan otot. Kekuatan efek aktivitas fisik terhadap kebugaran sangat bervariasi tergantung pada dosis aktivitas fisik (intensitas, durasi, frekuensi). Meskipun demikian, aktivitas fisik dipastikan akan berdampak terhadap kebugaran seseorang pada seluruh tingkatan aktivitas fisik (ringan, sedang, berat). ${ }^{23}$

Penelitian ini juga mengamati faktor lain yaitu keikutsertaan anak dalam bimbingan belajar, kemampuan sosial ekonomi keluarga, dan tingkat pendidikan orang tua. Namun, dalam penelitian ini ketiga faktor tersebut diketahui tidak berhubungan dengan prestasi belajar subjek. Tidak adanya hubungan faktor-faktor diatas dengan prestasi belajar subjek mungkin dikarenakan adanya faktor lain yang dalam penelitian ini tidak diamati seperti lingkungan sekolah dan psikologi anak. Sekolah merupakan lembaga pendidikan formal pertama yang menentukan keberhasilan belajar siswa. Lingkungan sekolah meliputi kurikulum, guru, dan sarana-prasarana pendidikan. Kurikulum merupakan penentu pokok pendidikan, sementara guru berperan sebagai penerjemah dan aplikator kurikulum kepada siswa, memberikan dukungan dan motivasi kepada siswa, dan memperlihatkan teladan yang baik khususnya dalam hal belajar. Kurikulum yang kurang baik, adanya gangguan pada guru, dan sarana-prasarana pendidikan yang kurang memadai akan menimbulkan ketidaknyamanan aktifitas belajar di sekolah sehingga mempengaruhi prestasi belajar siswa. ${ }^{24}$

Psikologi anak juga mempengaruhi prestasi belajar anak. Aspek psikologi meliputi Intelligence Quotient (IQ), minat, motivasi, dan bakat. Tingkat intelegensi (IQ) anak sangat menentukan tingkat keberhasilan belajar anak, dimana IQ yang tinggi memberi peluang lebih besar untuk meraih prestasi belajar yang baik. IQ dapat mempengaruhi prestasi belajar, tetapi hal tersebut tidak akan terjadi apabila tidak terdapat minat dan motivasi belajar terhadap materi terkait. ${ }^{25}$ Minat dan motivasi berkaitan erat, minat adalah kecenderungan hati yang tinggi terhadap sesuatu, sedangkan motivasi adalah kecenderungan anak dalam melakukan kegiatan belajar yang didorong oleh hasrat untuk mencapai prestasi. Penelitian pada anak non-stunting di Surakarta menunjukkan adanya hubungan positif antara motivasi anak dengan prestasi belajar. ${ }^{26}$ Bakat adalah potensi dan kemampuan yang secara unik dimiliki anak sejak lahir. Anak akan lebih mudah mempelajari sesuatu apabila sesuai dengan bakatnya. Sebaliknya, anak akan menjadi cepat bosan, dan merasa tidak senang apabila tidak sesuai dengan bakatnya. Hal tersebut akan tampak pada siswa melalui suka mengganggu dan gaduh di kelas, serta tidak mau belajar sehingga prestasinya rendah..$^{27,28}$

\section{SIMPULAN}

Kebugaran fisik terbukti berhubungan dengan prestasi belajar anak stunting, dimana semakin baik kebugaran fisik anak stunting maka prestasi belajarnya juga semakin baik. Asupan energi, protein, dan seng tidak terbukti memiliki hubungan dengan prestasi belajar anak stunting. Sosial ekonomi keluarga dan tingkat pendidikan orang tua tidak berhubungan dengan prestasi belajar anak stunting.

\section{SARAN}

Asupan zat gizi yang adekuat pada anak stunting perlu diupayakan. Meskipun pada penelitian ini tidak ditemukan hubungan, tetapi asupan zat gizi yang adekuat pada masa anak-anak sangat diperlukan untuk menunjang tumbuh kembangnya, terlebih pada gizi kurang.

\section{DAFTAR PUSTAKA}

1. Arisman. Gizi dalam Daur Kehidupan: Buku Ajar Ilmu Gizi. Jakarta: Buku Kedokteran EGC; 2004.

2. Kar B.R., Rao S.L., Chandramouli B.A. Cognitive development in children with chronic protein energy malnutrition. Biomed Central: Behavioral and Brain Functions: 2008; 4(31).

3. Levitsky D.A., Strupp B.J. Malnutrition and the brain: changing concepts, changing concerns. J.Nutr ; 1995: 125: p.2212-2220.

4. Kim HYP, Frongillo EA, Han SH, Oh SY, Kim WK, Jang YA, et al. Academic Performance of Korean Children is Associated with Dietary Behaviours and Physical Status. Asia Pacific Journal Clinical Nutrition. 2003; 12 (2): 186-192.

5. Seol AK, Bog HL. Relationships between the Nutrient Intake Status, Dietary Habits, 
Academic Stress and Academic Achievement in the Elementary School Children in Bucheon-si. Korean J Nutr:2008;41(8).p.786796

6. Kleinman RE, Hall S, Green H, KorzecRamizera D, Patton K, Pagano ME, Murphy JM. Diet, Breakfast, and Academic Performance in Children. Ann Nutr Metab: 2002; 46(1): p.24-30.

7. Benton D, Parker PY. Breakfast, blood glucose, and cognition. Am J Clin Nutr: 1998; 67: p.772-778.

8. Mahoney CR, Taylor HA, Kanarek RB, Samuel P. Effect of breakfast composition on cognitive processes in elementary school children. Elsevier: 2005; 85: p.635-645.

9. Tarigan ET. Hubungan Asupan Energi, Asupan Protein, Status Gizi Terhadap Tingkat Prestasi Akademik Siswa Akselerasi Dan Non Akselerasi Di SMA N 2 Bandar Lampung Tahun Ajaran 2011/2012. Medical Journal of lampung University:2012;1(1).

10. Jakobsen LH, Kondrup J, Zellner M, Tetens I, Roth E. Effect of a high protein meat diet on muscle and cognitive functions: A randomised controlled dietary intervention trial in healthy men. Elsevier: 2011: p.1-9

11. Bhatnagar S, Taneja S. Zinc and cognitive development. British Journal of Nutrition: 2001; 85: p.139-145.

12. Eveland-Sayer BM, Farley RS, Fuller DK, Morgan DW, Caputo JL. Physical Fitness and Academic Achievement in Elementary School Children. Journal of Physical Activity and Health 2009; 6: 99-104.

13. Taras, H. Physical activity and student performance at school. Journal of School Healt: 2005; 75: p.214-218.

14. Fleshner M. Exercise and neuroendocrine regulation of antibody production: protective effect of physical activity on stress-induced suppression of the specific antibody response. International Journal Sports Medicine: 2000; 21:p.4-19.

15. Badan Penelitian dan Pengembangan Kesehatan Departeman Kesehatan RI. Laporan hasil Riset Kesehatan Dasar 2013. Jakarta; 2013.

16. Dinas Kesehatan. Laporan Hasil Pemantauan Status Gizi Balita di Kabupaten Grobogan Tahun 2014. Purwodadi; 2014.

17. Henningham H.B., McGregor S.G.. Gizi dan perkembangan anak. Dalam buku [Gibney M.J., Margetts B.M., Kearney J.M., Arab L..
Gizi kesehatan masyarakat. 2009. Jakarta: penerbit buku kedokteran EGC. p. 302-323.

18. Levitsky D.A., Strupp B.J. Malnutrition and the brain: changing concepts, changing concerns. J.Nutr ; 1995: 125: p.2212-2220.

19. Gallagher M.L.. The nutrients and their metabolism. Dalam buku [Mahan L.K., Escott-stump S.. Krause's food and nutrition therapy: 12th edition. Missouri: sanders elsevier. 2008. p. 42-135]

20. Sastroasmoro S., Ismael S.. Dasar-dasar metodologi penelitian klinis. Jakart: Sagung seto. 2014.

21. Chung S.C., Iwaki S., Tack G.R., Yi J.H., You J.H., Kwon J.H. Effect of 30\% oxygen administration on verbal cognitive performance, blood oxygen saturation and heart rate. Appl Psychophysiol Biofeedback.; 2006: 31(4): p.281-293.

22. Turken AU. A Neuropsychological Theory of Positive Affect and Its Influence on Cognition. Psychological review: 1999; 106(3): p.529-550.

23. William M.H.. Nutrition for health, fitness, \& sport: eight edition. 2007. New york: McGraw-Hill. p.4-8.

24. Sundari N. Perbandingan Prestasi Belajar Antara Siswa Sekolah Dasar Unggulan dan Siswa Sekolah Dasar Non-Unggulan di Kabupaten Serang. Jurnal Pendidikan Dasar. 2008

25. Soemanto, Wasty. Psikologi Pendidikan. Jakarta: PT Rineka Cipta. 2006.

26. Yulianto Y. Hubungan antara jenjang pendidikan orang tua dan motivasi belajar dengan prestasi belajar sosiologi pada siswa kelas XI SMA Negeri I Surakarta tahun ajaran 2010/2011. Surakarta: Universitas Sebelas Maret. 2011

27. Abu A., Widodo S. Psikologi Belajar. Jakarta: Rineka Cipta.2004.

28. Syah, Muhibbin. Psikologi Pendidikan. Bandung: PT Remaja Rosdakarya. 2010. 